\title{
ТЕРАПЕВТИЧНИЙ РОЗДІЛ
}

DOI 10.35220/2078-8916-2020-37-3-17-24

УДК 616.31-08.039.71

О. В. Павленко, д.мед. н,

"М. В. Кривцова, к. біол. Н., О. О. Случевська, О. М. Ступницька к.мед. н.

Інститут стоматології, Національна медична академія післядипломної освіти імені П. Л. Шупика, Київ

"Державний вищий навчальний заклад

«Ужгородський національний університет»

\section{ДОСЛІДЖЕННЯ ПРОТИМІКРОБНИХ ВЛАСТИВОСТЕЙ КОМПОЗИЦЇ̈ \\ ДЛЯ ЛІКУВАННЯ ЗАПАЛЬНИХ УРАЖЕНЬ ПАРОДОНТУ ВІТЧИЗНЯНОГО ВИРОБНИЦТВА}

Ціль дослідження. Запально-деструктивні захворювання пародонту в світі становлять не тільки загальномедичну, а й соціально-економічну проблему, яка спонукає до пошуку нових методів лікування та діагностики. Сучасні кониепиії лікування хронічного генералізованого пародонтиту передбачають застосування комплексу терапевтичних, ортопедичних, хірургічних і ортодонтичних методів лікування, $і$ доволі часто їх ефективність є сумнівною.

На сьогодні загальновизнаним препаратом вибору в пародонтологї є хлоргексидину біглюконат (та його інші сполуки), оскільки він здатний пригнічувати ріст $i$ формування колоній понад 80,00\% мікроорганізмів біоплівки ротової порожнини.

Також у клінічній практиці застосовують протимікробні препарати системної діï, особливо у випадках агресивних і важких форм генералізованого пародонтиту, що виникають на фоні загальносоматичної патологї̈, а також при ускладненнях хірургічних втручань.

Матеріали та методи дослідження. Для проведення досліджень використовували типові музейні культуpu ATTC (American Type Culture Collection, USA) Candida albicans ATCC 885-653; Staphylococcus aureus ATCC 25923; Escherichia coli ATCC 25922, Enterococcus faecalis ATCC 29212, Streptococcus pyogenes ATCC 19615, та клінічні культури ізольовані із ротової порожнини людей із запальними захворюваннями: мікроскопічні гриби роду Candida (C. albicans) Staphylococcus aureus, Escherichia coli, Streptococcus pyogenes, Enterococcus faecalis.

Мінімальну бактерицидну та інгібуючу концентрацію досліджуваного гелю визначали у полістиролових пластикових 96-лункових планшетах.

Результати дослідження та ӥх обговорення. Результати дослідження показали, що досліджуваний гель та розчин хлоргексидину біглюконат 0,05\% чинили активний вплив на музейні та клінічні штами лабораторних мікроорганізмів.

Висновки. Отже, досліджуваний гель для лікування запальних уражень пародонту вітчизняного виробни- иттва "Джен-Метрогелур» виявився ефективним протимікробним засобом відносно клінічних та лабораторних итамів мікроорганізмів. Високочутливими до засобу виявилися клінічні та музейні культури $C$. albicans. Чутливими до гелю були культури S. aureus та музейні штами S. pyogenes та E. coli. Помірно чутливими виявилися культури E. faecalis та клінічні итами $S$. pyogenes ma E. coli.

Ключові слова: захворювання пародонту, протимікробні препарати, мікроскопічні гриби, гель.

\section{А. В. Павленко, "М. В. Кривцова, Е. А. Случевская, Е. Н. Ступницкая}

Институт стоматологии, Национальная медицинская академия последипломного образования им. П. Л. Шупика, Киев

Государственное высшее учебное заведение «Ужгородский национальный университет»

\section{ИССЛЕДОВАНИЕ ПРОТИВОМИКРОБНЫХ СВОЙСТВ КОМПОЗИЦИИ ДЛЯ ЛЕЧЕНИЯ ВОСПАЛИТЕЛЬНЫХ ПОРАЖЕНИЙ ПАРОДОНТА ОТЕЧЕСТВЕННОГО ПРОИЗВОДСТВА}

Цель исследования. Воспалительно-деструктивные заболевания пародонта в мире составляют не только общемедииинскую, но и социально-экономическую проблему, которая побуждает к поиску новых методов лечения и диагностики. Современные концепции лечения хронического генерализованного пародонтита предусматривают применение комплекса терапевтических, ортопедчческих, хирургических и ортодонтических методов лечения, и довольно часто их эффективность сомнительна.

На сегодня общепризнанным препаратом выбора в пародонтологии является хлоргексидина биглюконат (и его другие соединения), поскольку он способен подавлять рост и формирование колоний более 80,00\% микроорганизмов биопленки ротовой полости.

Также в клинической практике применяют противомикробные препараты системного действия, особенно в случаях агрессивных и тяжелых форм генерализованного пародонтита, возникающих на фоне общесоматической патологии, а также при осложнениях хирургических вмешательств.

Материалы и методы исследования. Для проведения исследований использовали типичные музейные кульmypы ATTC (American Type Culture Collection, USA) Candida albicans ATCC 885-653; Staphylococcus aureus ATCC 25923; Escherichia coli ATCC 25922, Enterococcus faecalis ATCC 29212, Streptococcus pyogenes ATCC 19615, и клинические культуры изолированных из ротовой полости людей с воспалительными заболеваниями: микроскопические грибы рода Candida (C. albicans) Staphylococcus aureus, Escherichia coli, Streptococcus pyogenes, Enterococcus faecalis. 
Минимальную бактерииидную и ингибируюшу концентрацию исследуемого геля определяли в полистироловые пластиковых 96-луночных планшетах.

Результаты исследования и их обсуждение. Результаты исследования показали, что исследуемый гель и раствор хлоргексидина биглюконат 0,05\% оказывали активное влияние на музейные и клинические штаммы лабораторных микроорганизмов.

Выводы. Итак, исследуемый гель для лечения воспалительных поражений пародонта отечественного производства «Джен-Метрогелур» оказался эффективным противомикробным средством в отношении клинических и лабораторных итаммов микроорганизмов. Высокочувствительными к средству оказались клинические и музейные культуры C. albicans. Чувствительными к гелю были культуры $S$. аигеи $u$ музейные итаммы $S$. pyogenes и E. coli. Умеренно чувствительными оказались культуры E. faecalis $u$ клинические итаммы S. pyogenes и E. coli.

Ключевые слова: заболевания пародонта, противомикробные препараты, микроскопические грибы, гель.

\section{O. V. Pavlenko, *M. V. Kryvcova, O. O. Sluchevs'ka, O. M. Stupnyc'ka}

Institute of Dentistry, P. L. Shupyk National Medical Academy of postgraduate education, Kyiv *State Higher Educational Institution "Uzhgorod National University»

\section{STUDY OF ANTIMICROBIAL PROPERTIES OF THE COMPOSITION FOR THE TREATMENT OF INFLAMMATORY PERIODONTAL LESIONS OF DOMESTIC PRODUCTION}

\footnotetext{
ABSTRACT

Purpose of research. The purpose of the study. Inflammatory and destructive periodontal diseases in the world are not only a General medical, but also a socio-economic problem that encourages the search for new methods of treatment and diagnosis. Modern concepts of treatment of chronic generalized periodontitis involve the use of a complex of therapeutic, orthopedic, surgical and orthodontic methods of treatment, and quite often their effectiveness is questionable.

Today, the recognized drug of choice in Periodontology is chlorhexidine bigluconate (and its other compounds), since it is able to inhibit the growth and formation of colonies of more than $80.00 \%$ of microorganisms in the oral biofilm.

Also in clinical practice, antimicrobial agents of systemic action are used, especially in cases of aggressive and severe forms of generalized periodontitis that occur against the background of General somatic pathology, as well as in complications of surgical interventions.

Materials and methods of research. Typical Museum cultures ATTC (American Type Culture Collection, USA) Candida albicans ATCC 885-653; Staphylococcus aureus ATCC 25923; Escherichia coli ATCC 25922, Enterococcus faecalis ATCC 29212, Streptococcus pyogenes ATCC 19615, and clinical cultures isolated from the oral cavity
}

of people with inflammatory diseases: microscopic fungi of the genus Candida (C. albicans) Staphylococcus AUREUS, Escherichia coli, Streptococcus pyogenes, Enterococcus faecalis.

The minimum bactericidal and inhibitory concentration of the test gel was determined in polystyrene plastic 96-well tablets.

The results of the study and their discussion. The results of the study showed that the test gel and a solution of chlorhexidine bigluconate $0.05 \%$ had an active effect on Museum and clinical strains of laboratory microorganisms.

Conclusions. So, the investigated gel for the treatment of inflammatory periodontal lesions of domestic production "gen-Metrogelur» proved to be an effective antimicrobial agent against clinical and laboratory strains of microorganisms. Clinical and Museum cultures of C. albicans were highly sensitive to the drug. S. aureus cultures and Museum strains of S. pyogenes and E. coli were sensitive to the gel. E. faecalis cultures and clinical strains of $S$. pyogenes and E. coli were moderately sensitive.

Key words: periodontal diseases, antimicrobials, microscopic fungi, gel.

Актуальність теми дослідження. В сучасних умовах актуальність вивчення питань діагностики та лікування запально-деструктивних уражень пародонту має беззаперечну аргументацію, в першу чергу, з огляду на високу поширеність патології - вона вражає понад 85,00 \% населення країни. Хонічний генералізований пародонтит належить до провідних причин втрати зубів, також і в пацієнтів молодого і працездатного віку [1,2]. Відповідно до результатів стоматологічних епідеміологічних досліджень 2007-2008 років за критеріями ВОО3, поширеність ознак ураження тканин пародонту (кровоточивість ясен, наявність зубного каменю, пародонтальних кишень глибиною 4-5 мм) в осіб віком 35-44 років досягає 80,00\% і більше [3,4].

Запально-деструктивні захворювання пародонту в світі становлять не тільки загальномедичну, а й соціально-економічну проблему, яка спонукає до пошуку нових методів лікування та діагностики. Сучасні концепції лікування хронічного генералізованого пародонтиту передбачають застосування комплексу терапевтичних, ортопедичних, хірургічних і ортодонтичних методів лікування, і доволі часто їх ефективність $\epsilon$ сумнівною. Значний практичний i науковий iнтерес сьогодні становить напрямок місцевого медикаментозного лікування, котре дозволяє ліквідувати вогнища хронічного і гострого запалення, стабілізувати стан тканин пародонта, а також створити сприятливі умови для подальшого хірургічного лікування. Основу сучасного медикаментозного лікування запальних захворювань пародонта складають антисептичні та антибакте- 
ріальні лікарські засоби. В клінічній практиці застосовується широкий спектр препаратів і композицій: 0,05 \% розчин хлоргексидину, 0,01\% розчин мірамістину, $3,00 \%$ розчин перекису водню, 0,02 \% розчин фурациліну, $0,10 \%$ розчин перманганату калію. Доволі часто використовують антисептики, що містять полівінілпіролідон йоду, $0,02 \%$ декаметоксин у фізіологічному розчині хлориду натрію, октенідин на основі феноксіетанолу [5-8].

На сьогодні загальновизнаним препаратом вибору в пародонтології є хлоргексидину біглюконат (та його інші сполуки), оскільки він здатний пригнічувати ріст і формування колоній понад 80,00\% мікроорганізмів біоплівки ротової порожнини. Зазвичай поверхню зубів, ортопедичних конструкцій, дентальних імплантатів та СОПР колонізують бактеріальні клітини, в стінках яких присутні аніонні групи (сульфати, фосфати, карбоксильні групи), що мають негативний заряд, що зумовлює адгезію до них позитивно заряджених сполук бісбігуаніду (хлоргексидину). Тому встановлено, що концентрація антисептика в порожнині рота після одноразового застосування може зберігається протягом тривалого періоду, залежно від кратності і тривалості використання, від 8 годин до 11 тижнів. Такі явища пояснюють здатністю хлоргексидину зв'язувати карбоксильні групи муцину слини та заміщати іони кальцію, які виділяються слинними залозами. Сполука є ефективною щодо вірусів, грибів роду Кандида, грам-позитивних та грам-негативних, аеробних і анаеробних бактерій, та не порушує функціональну активність лактобацил і біфідобактерій $[9,10]$.

Також у клінічній практиці застосовують протимікробні препарати системної дії, особливо у випадках агресивних і важких форм генералізованого пародонтиту, що виникають на фоні загальносоматичної патології, а також при ускладненнях хірургічних втручань. Найчастіше застосовують такі антибіотики та фторхінолони: метронідазол, лінкоміцин, кліндаміцин, азитроміцин, мидекамицин, рокситроміцин, доксициклін, граміцидин С, амоксицилін, офлоксацин, ципрофлоксацин. Одним основних антибіотиків, що діють на анаеробну мікрофлору, є метронідазол. Тому в практичній стоматології можна знайти ряд спеціальних композицій, в яких він виступає діючою речовиною самостійно, а також у комбінації з іншими активними компонентами. Дослідження такого характеру є необхідними для формування системи реального інфекційного контролю в практичній стоматології $[11,12,13]$.

Саме перераховане вище дозволило сформувати мету цього дослідження - дослідити протимікробну активність вітчизняного гелю для ліку- вання захворювань пародонту «ДженМетрогелур» шляхом визначення зон затримки росту клінічних і музейних тест-культур мікроорганізмів, визначення мінімальної бактерицидної та інгібуючої концентрацій гелю.

Матеріали та методи дослідження. Композиція гелю «Джен-Метрогелур» містить 4 активні терапевтичні компоненти (в перерахунку на 100,00 г): хлоргексидину діацетат - 0,5 г; метронідазолу бензоат $-5,00$ г; гідрокортизону ацетат - 0,10 г; 6-метилурацил - 0,20 г. Метронідазолу бензоат - похідне 5-нітроімідазолу, антипротозойний і антибактеріальний засіб. Механізм дії сполуки полягає в біохімічному відновленні 5-нітрогрупи метронідазолу внутрішньоклітинними транспортними протеїнами анаеробних мікроорганізмів і найпростіших, що призводить до загибелі саме таких мікроорганізмів. Препарат здатний чинити вплив в тому числі й на пародонтопатогенні мікроорганізми. Хлоргексидину діацетат - сіль катіонного полібігуанідину (хлоргексидин), який є загальновизнаним антисептиком, що віднесений $\mathrm{BOO} 3$ до переліку найважливіших медичних засобів, необхідних для забезпечення базових потреб охорони здоров'я. Застосовується в стоматології понад 60 років, володіє бактеріостатичною і бактерицидною дією. Механізм впливу полягає в ушкодженні негативно зарядженої мембрани бактеріальної клітини в ході дисоціації антисептика в розчинах. Сполуки хлоргексидину активні щодо грам-позитивних і грам-негативних бактерій, факультативних анаеробів, аеробів і окремих грибів. Гідрокортизону ацетат - належить до групи глюкокортикостероїдів природного походження (аналоги природних гормонів наднирників). Засіб викликає протишокову, антитоксичну, імуносупресивну, антиексудативну, протисвербіжну, протизапальну, десенсибілізуючу, антиалергічну дію. 6-Метилурацил - $є$ нестероїдним анаболічним засобом. Має анаболічну та антикатаболічну дію, прискорює регенерацію, загоєння ран, стимулює клітинні й гуморальні ланки імунітету, чинить протизапальну дію. Характерною специфічною властивістю препарату є стимулюючий вплив на еритро- $\mathrm{i}$ особливо лейкопоез.

Для проведення досліджень використовували типові музейні культури АТTC (American Type Culture Collection, USA) Candida albicans ATCC 885-653; Staphylococcus aureus ATCC 25923; Escherichia coli ATCC 25922, Enterococcus faecalis ATCC 29212, Streptococcus pyogenes АТСС 19615, та клінічні культури ізольовані із ротової порожнини людей із запальними захворюваннями: мікроскопічні гриби роду Candida (C. albicans) Staphylococcus aureus, Escherichia coli, Streptococcus pyogenes, Enterococcus faecalis. 
Чутливість мікроорганізмів до препаратів визначали методом дифузії в агар (діаметр лунки 8 мм). Інокулят бактерій або мікроскопічних грибів у кількості 0,1 мл у фізіологічному стерильному розчині відповідно 0.5Mc Farland стандарту висівали на Мюллер-Хінтон-агар для бактерій та Сабуро-агар для грибів роду Candida. Досліджуваний препарат вносили у лунку у кількості 20 мкл. Облік результатів проводили через 24 год після інкубації у термостаті при температурі $37,00^{\circ} \mathrm{C}$ для бактерій та 48 год при температурі $35,00^{\circ} \mathrm{C}$ для мікроскопічних грибів. Діаметр зон затримки росту вимірювали в міліметрах, включаючи діаметр лунки. Всі досліди проводили у трикратній повторності. Оцінювали результат за діаметром затримки росту мікроорганізмів навколо лунки. Діаметр до 15 мм - мікроорганізми нечутливі до антисептиків, від 16 до 20 мм - мікроорганізми помірно чутливі до антисептиків, від 21 до 25 мм - мікроорганізми чутливі до антисептиків, від 26 мм і більше - мікроорганізми високочутливі до антисептиків.

Мінімальну бактерицидну та інгібуючу концентрацію досліджуваного гелю визначали у полістиролових пластикових 96-лункових планше- тах. Досліджуваний матеріал розводили у м'ясопептонному бульйоні у співвідношенні: $1: 2$; $1: 4 ; 1: 6 ; 1: 8$. Суспензію культури мікроорганізмів вносили у кількості 10 мкл 0.5 McFarland $\left(1,5 \times 10^{8}\right.$ КУО/мл). Через 24 години інкубації бактерій та 48 - мікроскопічних грибів висівали на середовище Мюллер-Хінтона. За мінімальну бактерицидну концентрацію вважали лунку, в якій не спостерігалось росту мікроорганізмів, за мінімальну бактеріостатичну - лунку, в якій спостерігали затримку росту культури. Паралельно було досліджено вплив на культури мікроорганізмів розчину хлоргексидину біглюконату 0,05\%, метронідазолу бензоату 1,0 \% та плазми крові, збагаченої тромбоцитами (отримана від здорового донора в пробірку із цитратом натрію, центрифугована на швидкості 2000 обертів за хвилину протягом 10 хв). В якості контролю був використаний стерильний фізіологічний розчин хлориду натрію [14,15]. Весь комплекс досліджень було проведено на базі бактеріологічної лабораторії кафедри генетики, фізіології рослин та мікробіології біологічного факультету ДВНЗ «Ужгородський національний університет».

Таблиця 1

Вплив гелю «Джен-Метрогелур» та його окремих компонентів на типові й клінічні штами мікроорганізмів, мм, $\mathrm{M} \pm \mathbf{m}$

\begin{tabular}{|c|c|c|c|c|c|c|}
\hline Тест культури & $\begin{array}{c}\text { Гель без } \\
\text { розведення }\end{array}$ & $\begin{array}{c}\text { Гель у } \\
\text { розведенні } \\
1: 2\end{array}$ & $\begin{array}{c}\text { Хлор-гексидину } \\
\text { біглюконат } \\
0,05 \%\end{array}$ & $\begin{array}{c}\text { Метро- } \\
\text { нідазол } \\
1,0 \%\end{array}$ & $\begin{array}{c}\text { Плазма } \\
\text { крові }\end{array}$ & $\begin{array}{l}\text { Фізіологіч- } \\
\text { ний розчин }\end{array}$ \\
\hline S. aureus ATCC 25923 & $\begin{array}{c}21,67 \pm 0,44 \\
(\mathrm{M}=22,00)\end{array}$ & $\begin{array}{l}20,83 \pm 0,22 \\
(\mathrm{M}=21,00)\end{array}$ & $\begin{array}{l}19,33 \pm 0,44 \\
(\mathrm{M}=19,00)\end{array}$ & $-*$ & - & - \\
\hline $\begin{array}{l}\text { S. aureus клінічний } \\
(\mathrm{n}=5)\end{array}$ & $\begin{array}{l}23,50 \pm 0,33 \\
(\mathrm{M}=23,50)\end{array}$ & $\begin{array}{l}21,67 \pm 0,44 \\
(\mathrm{M}=22,00)\end{array}$ & $\begin{array}{l}18,33 \pm 0,44 \\
(\mathrm{M}=18,00)\end{array}$ & - & - & - \\
\hline $\begin{array}{l}\text { S. pyogenes ATCC } \\
19615\end{array}$ & $\begin{array}{l}21,67 \pm 0,44 \\
(\mathrm{M}=22,00)\end{array}$ & $\begin{array}{l}20,67 \pm 0,44 \\
(M=21,00)\end{array}$ & $\begin{array}{l}10,67 \pm 0,44 \\
(\mathrm{M}=11,00)\end{array}$ & - & - & - \\
\hline $\begin{array}{l}\text { S. pyogenes клінічний } \\
(\mathrm{n}=5)\end{array}$ & $\begin{array}{l}20,33 \pm 0,44 \\
(\mathrm{M}=20,00)\end{array}$ & $\begin{array}{l}20,83 \pm 0,22 \\
(\mathrm{M}=21,00)\end{array}$ & $\begin{array}{l}11,33 \pm 0,44 \\
(\mathrm{M}=11,00)\end{array}$ & - & - & - \\
\hline E. coli ATCC 25922 & $\begin{array}{l}21,67 \pm 0,44 \\
(\mathrm{M}=22,00)\end{array}$ & $\begin{array}{l}20,67 \pm 0,44 \\
(\mathrm{M}=21,00)\end{array}$ & $\begin{array}{l}17,77 \pm 0,22 \\
(\mathrm{M}=17,00)\end{array}$ & - & - & - \\
\hline $\begin{array}{l}\text { E. coli клінічний } \\
(\mathrm{n}=5)\end{array}$ & $\begin{array}{l}20,17 \pm 0,22 \\
(\mathrm{M}=20,00)\end{array}$ & $\begin{array}{l}20,67 \pm 0,44 \\
(M=21,00)\end{array}$ & $\begin{array}{l}16,33 \pm 0,22 \\
(\mathrm{M}=16,50)\end{array}$ & - & - & - \\
\hline $\begin{array}{l}\text { E. faecalis ATCC } \\
29212\end{array}$ & $\begin{array}{r}20,67 \pm 0,44 \\
(\mathrm{M}=20,00)\end{array}$ & $\begin{array}{l}20,17 \pm 0,22 \\
(\mathrm{M}=20,00)\end{array}$ & $\begin{array}{l}18,33 \pm 0,44 \\
(\mathrm{M}=18,00)\end{array}$ & - & - & - \\
\hline $\begin{array}{l}\text { E. faecalis клінічний } \\
(\mathrm{n}=5)\end{array}$ & $\begin{array}{l}20,50 \pm 0,33 \\
(\mathrm{M}=20,50)\end{array}$ & $\begin{array}{l}20,33 \pm 0,22 \\
(M=20,50)\end{array}$ & $\begin{array}{l}17,33 \pm 0,44 \\
(\mathrm{M}=17,00)\end{array}$ & - & - & - \\
\hline $\begin{array}{l}\text { C. albicans ATCC 885- } \\
653\end{array}$ & $\begin{array}{l}41,33 \pm 0,44 \\
(\mathrm{M}=41,00)\end{array}$ & $\begin{array}{l}40,80 \pm 0,53 \\
(\mathrm{M}=41,00)\end{array}$ & $\begin{array}{l}15,83 \pm 0,56 \\
(\mathrm{M}=16,00)\end{array}$ & - & - & - \\
\hline $\begin{array}{l}\text { C. albicans клінічний } \\
(\mathrm{n}=5)\end{array}$ & $\begin{array}{l}35,67 \pm 0,44 \\
(\mathrm{M}=36,00)\end{array}$ & $\begin{array}{l}38,33 \pm 0,44 \\
(\mathrm{M}=38,00)\end{array}$ & $\begin{array}{l}14,50 \pm 0,33 \\
(\mathrm{M}=14,50)\end{array}$ & - & - & - \\
\hline
\end{tabular}

Пр им і т ка: «-» зона затримки росту відсутня;

Результати дослідження та ӥх обговорення. Результати дослідження показали, що досліджуваний гель та розчин хлоргексидину біглюконат 0,05 \% чинили активний вплив на музейні та клінічні штами лабораторних мікроорганізмів (табл. 1). Найбільш виражена зона затримки росту культури відзначалася при взаємодії досліджуваного гелю (як у нерозведеному вигляді, так i у розведеному $1: 2)$ із дріжджоподібними грибами $C$. albicans. Причому, музейна культура $C$. 
albicans ATCC 885-653 була більш чутлива, ніж клінічна культура $-41,33 \pm 0,44$ мм $(\mathrm{M}=41,00$ мм, нерозведений) і 40,80 $\pm 0,53$ мм (M=41,00 мм, ро3ведений) та $35,67 \pm 0,44$ мм (M=36,00 мм, нерозведений) і $38,33 \pm 0,44$ мм (M=38,00 мм, розведений). В той час як розчин хлоргексидину біглюконату $0,05 \%$ мав ефект вдвічі слабший при взаємодії з обидвома культурами C. albicans - діаметр затримки росту був $15,83 \pm 0,56$ мм $(\mathrm{M}=16,00)$ у музейного штаму та $14,50 \pm 0,33$ мм $(\mathrm{M}=14,50)$ у клінічного (рис. 1$)$.

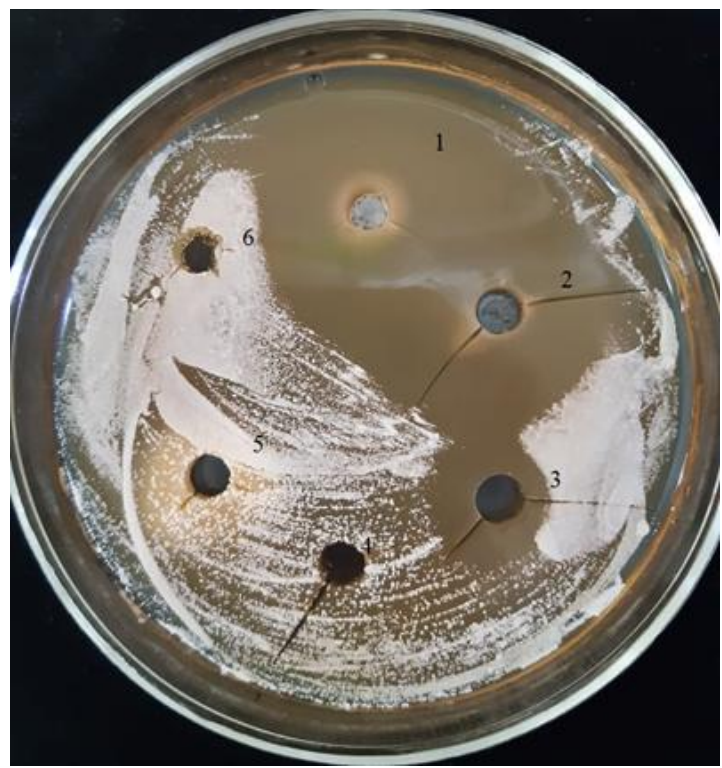

Рис. 1. Вплив активних компонентів на ріст клінічного ізоляту C. albicans: 1 - нерозведений гель; 2 - гель у розведенні 1:2; 3 - хлоргексидину біглюконат $0,05 \%$ (бактеріостатичний ефект); 4 - метронідазол $1,00 \% ; 5$ - фізіологічний розчин хлориду натрію; 6 - плазма крові.

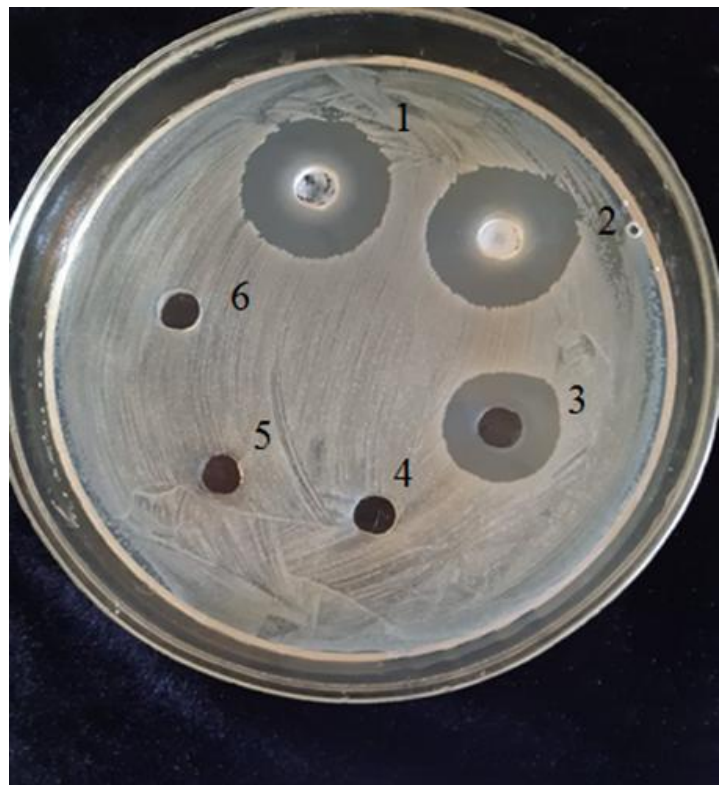

Рис. 2. Вплив активних компонентів на ріст клінічного ізоляту E. coli: 1 - нерозведений гель; 2 - гель у розведенні 1:2; 3 - хлоргексидину біглюконат $0,05 \% ; 4$ - метронідазол $1,00 \% ; 5$ - фізіологічний розчин хлориду натрію; 6 - плазма крові.

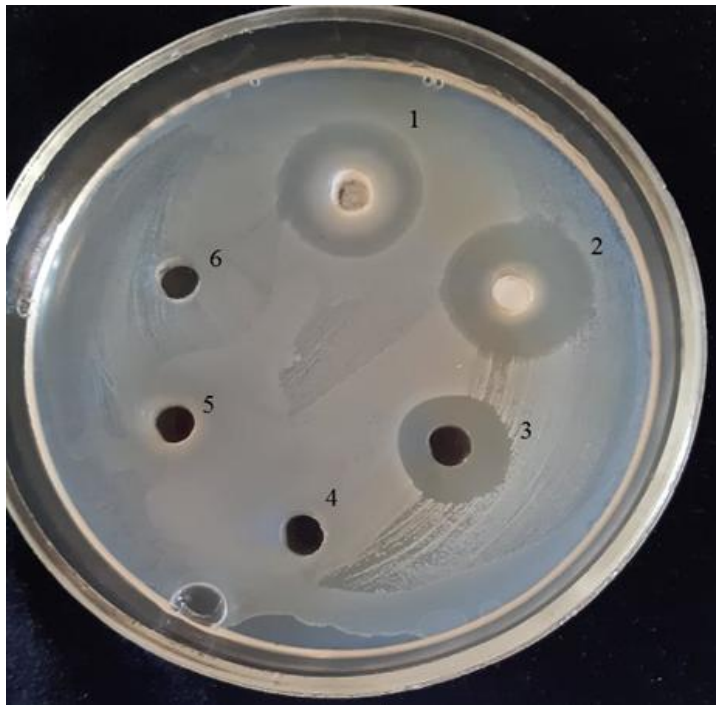

Рис. 3. Вплив активних компонентів на ріст клінічного ізоляту E. faecalis: 1 - нерозведений гель; 2 - гель у розведенні $1: 2 ; 3$ - хлоргексидину біглюконат $0,05 \% ; 4$ - метронідазол $1,00 \% ; 5$ - фізіологічний розчин хлориду натрію; 6 - плазма крові.

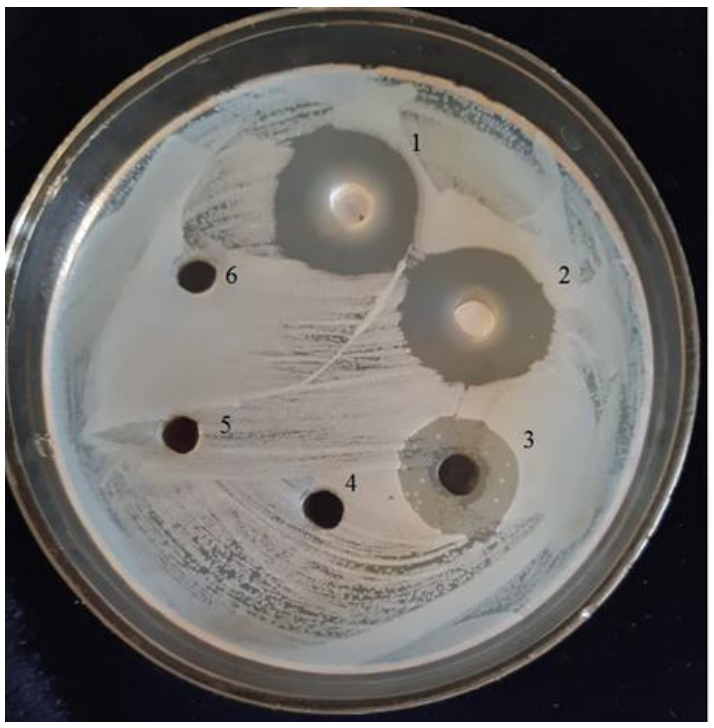

Рис. 4. Вплив активних компонентів на ріст клінічного ізоляту $S$. aureus: 1 - нерозведений гель; 2 - гель у розведенні $1: 2 ; 3$ - хлоргексидину біглюконат $0,05 \%$ (бактеріостатичний ефект); 4 - метронідазол $1,00 \% ; 5$ - фізіологічний розчин хлориду натрію; 6 - плазма крові.

Стосовно бактеріальних культур, то їх чутливість до розведеного та нерозведеного гелю «Джен-Метрогелур» відрізнялася незначно, як у клінічних, так і в музейних штамів - зони затримки росту були від 20,00 до 23,50 мм (рис. 2, 3, 4). Переважна більшість досліджуваних бактеріальних культур також була чутливою і до впливу окремо хлоргексидину біглюконату $0,05 \%$, діаметр зон затримки росту був менший на 15,00 $20,00 \%$, за винятком культур $S$. pyogenes ATCC 19615 та клінічного штаму. У S. pyogenes відзначалося зменшення зон затримки росту при застосуванні $0,0 \%$ розчину хлоргексидину біглюконату до 50,00\%. Це може свідчити про залежність 
росту таких мікроорганізмів від концентрації сполук хлоргексидину в середовищі, або про можливий вплив гелевої форми матеріалу, що може позитивно відбиватися на біологічній доступності активних речовин, або ж можливий вплив на мікроорганізми поверхневоактивних речовин, які присутні в композиції досліджуваного гелю. Також було відзначено відсутність затримки росту мікроорганізмів при пассажі культур в присутності 1,00 \% розчину метронідазолу та плазми крові, збагаченої тромбоцитами.

В подальшому було визначено мінімальні бактерицидні та інгібуючі концентрації гелю «Джен-Метрогелур» на ріст типових і клінічних штамів лабораторних мікроорганізмів. Було встановлено, що нерозведений гель володіє бактерицидним та мікоцидним впливом відносно культур S.aureus, E. faecalis та C. albicans. Чистий гель викликав бактеріостатичний ефект при взаємодії із культурами $S$. pyogenes та E. coli. При розведенні гелю 1:2 композиція викликала переважно бактеріостатичний (мікостатичний ефект) на культури $S$. aureus, $S$. pyogenes $i C$. albicans. Така концентрація гелю не впливала на бактерії кишкової групи - E. coli ma E. faecalis. При більшому розведенні гелю зникав бактеріостатичний ефект на всі досліджувані тесткультури (табл. 2). Стосовно змін кількості колонієутворюючих (КУО) одиниць досліджуваних тест-культур, то було виявлено, що нерозведений гель повністю пригнічував ріст $S$. aureus (клінічний і музейний штами), E. faecalis та $C$. albicans. 5-6 КУО/мл E. coli визначалося при застосуванні нерозведеного гелю та 25-27 КУО/мл S. pyogenes (табл. 3). При розведенні гелю 1:2 спостерігалося збільшення концентрації КУО тест-культур від 0 до 4-5 на мл у $S$. aureus, із 25-27 до 78-81 на мл у $S$. pyogenes та від 0 до $8-10$ КУО/мл у $C$. albicans. Достатньо інтенсивно змінювався ріст культур кишкової флори при розведенні гелю 1:2 - від бактерицидних властивостей до інтенсивного росту у E. faecalis та від 5-6 КУО/мл до інтенсивного росту в $E$. coli (рис. 5,6 ).

Таблиця 2

Визначення мінімальної бактерицидної та мінімальної інгібуючої концентрації гелю «Джен-Метрогелур» на типові та клінічні штами мікроорганізмів

\begin{tabular}{|c|c|c|c|c|c|}
\hline Тест культури & Нерозведений & $1: 2$ & $1: 4$ & $1: 6$ & $1: 8$ \\
\hline S.aureus ATCC 25923 & бактерицидна дія & бактеріостатична дія & $+*$ & + & + \\
\hline S.aureus клінічний & бактерицидна дія & бактеріостатична дія & + & + & + \\
\hline S. pyogenes ATCC 19615 & бактеріостатична дія & бактеріостатична дія & + & + & + \\
\hline S. pyogenes клінічний & бактеріостатична дія & бактеріостатична дія & + & + & + \\
\hline E. coli ATCC 25922 & бактеріостатична дія & + & + & + & + \\
\hline E. coli клінічний & бактеріостатична дія & + & + & + & + \\
\hline E. faecalis ATCC 29212 & бактерицидна дія & + & + & + & + \\
\hline E. faecalis клінічний & бактерицидна дія & + & + & + & + \\
\hline C. albicans ATCC 885-653 & мікоцидна & мікостатична дія & + & + & + \\
\hline C. albicans клінічний & мікоцидна & мікостатична дія & & - & - \\
\hline
\end{tabular}

Пр им і $т$ ка : «-» зона затримки росту відсутня; «+»- ріст культури, контроль - фізіологічний розчин натрію хлориду

Таблиця 3

Динаміка кількості колонісутворюючих одиниць культур тестових мікроорганізмів при застосуванні гелю «Джен-Метрогелур» різних концентрацій

\begin{tabular}{|c|c|c|}
\hline Тест-культури & Нерозведений & Розведення 1:2 \\
\hline S.aureus ATCC 25923 & 0 & 4 КУО/мл \\
\hline S.aureus клінічний & 0 & 5 КУО/мл \\
\hline S. pyogenes ATCC 19615 & 25 КУО/мЛ & 78 КУО/мЛ \\
\hline S. pyogenes клінічний & 27 КУО/мЛ & 81 КУО/мЛ \\
\hline E. coli ATCC 25922 & 5 КУО/мЛ & $1,55 \times 10^{8} \mathrm{KУО/мл}$ \\
\hline E. coli клінічний & 6 КУО/мл & $1,49 \times 10^{8} \mathrm{KУО/мл}$ \\
\hline E. faecalis ATCC 29212 & 0 & $1,43 \times 10^{8} \mathrm{КУО/мЛ}$ \\
\hline E. faecalis клінічний & 0 & $1,52 \times 10^{8} \mathrm{KУО/мЛ}$ \\
\hline C. albicans ATCC 885-653 & 0 & 8 КУО/мЛ КУО/мЛ \\
\hline C. albicans клінічний & 0 & 10 КУО/мл КУО/мл \\
\hline
\end{tabular}

Пр им і т ка: Контроль бактеріальних культур без внесення препарату $1,5 \times 10^{8} \mathrm{KУО} /$ мл 


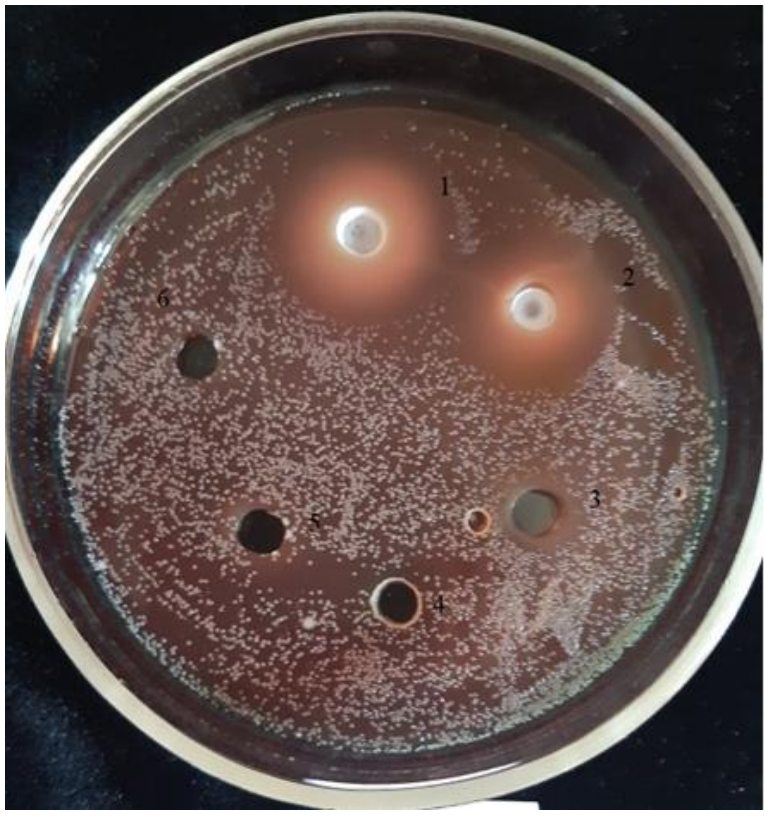

Рис. 5. Вплив активних компонентів на ріст клінічного ізоляту $S$. pyogenes: 1 - нерозведений гель; 2 - гель у розведенні $1: 2 ; 3$ - хлоргексидину біглюконат $0,05 \%$ (бактеріостатичний ефект); 4 - метронідазол 1,00\%; 5 - фізіологічний розчин хлориду натрію; 6 - плазма крові.

Висновки. Отже, досліджуваний гель для лікування запальних уражень пародонту вітчизняного виробництва «Джен-Метрогелур» виявився ефективним протимікробним засобом відносно клінічних та лабораторних штамів мікроорганізмів. Високочутливими до засобу виявилися клінічні та музейні культури $C$. albicans. Чутливими до гелю були культури $S$. aureus та музейні штами $S$. pyogenes та $E$. coli. Помірно чутливими виявилися культури $E$. faecalis та клінічні штами $S$. pyogenes та E. coli. Досліджувана композиція зберігала свою ефективність при розведенні 1:2, що свідчить про перспективність застосування іiі в клінічній практиці як ефективного засобу в комплексному лікуванні запальних та запальнодистрофічних захворювань пародонту. Протизапальний гель викликає бактерицидний і бактеріостатичний ефект на широкий перелік культур мікроорганізмів.

\section{Список літератури}

1. Исследование чувствительности к противомикробным средствам у микроорганизмов очага гнойного воспаления среди пациентов челюстно-лицевого стационара / М. А. Иванова, Ю. А. Мочалов, П. П. Брехличук [и др.] // Медицинские новости Грузии. - 2019. - №12 (297). - С.5763.

2. Singh R. Resective or regenerative periodontal therapy: Considerations during treatment planning: A case report / R Singh, S. S. Ramachandra // N Y State Dent J. - 2016. №82(4). - P.46-49.

3. Шилівський І. В. Сучасні погляди на етіологію та патогенез запальних захворювань пародонта, їх взаємозв'язок із патологією сечовидільної системи / І. В. Шилівський, О. М. Немеш, 3. М. Гонта // Буковинський медичний вісник. - 2016. -№20(1). - С.224-227.

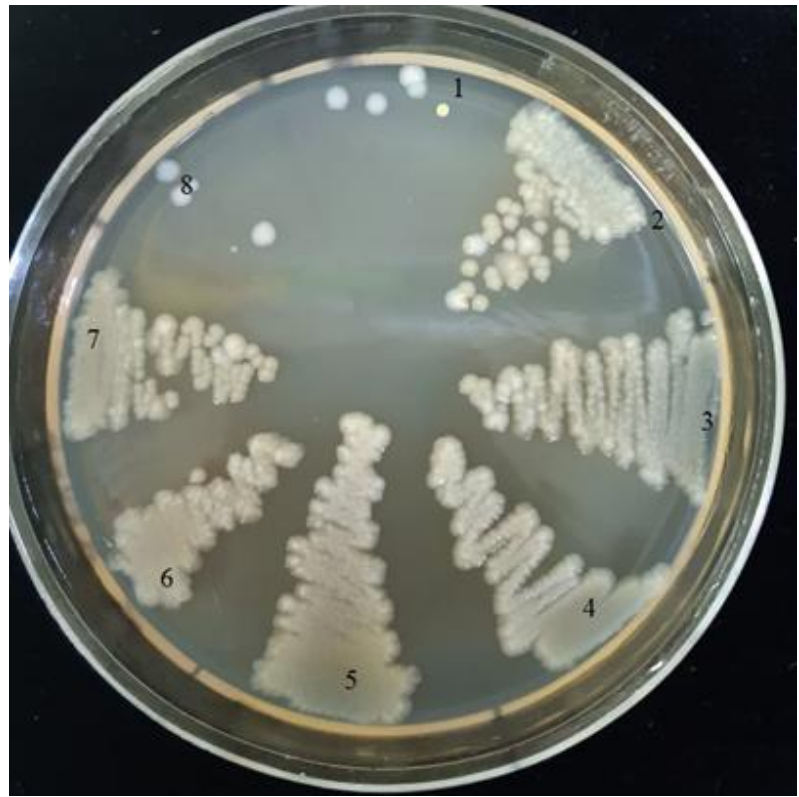

Рис. 6. Визначення мінімальних бактерицидних та мінімальних інгібуючих концентрацій гелю щодо $S$. aureus: 1,8 бактеріостатичний ефект.

4. Січкоріз Х. А. Клінічно-лабораторне обгрунтування комплексного лікування та профілактики захворювань пародонта у хворих із хронічним гепатитом $\mathrm{C}$ : автореф. дис. на здобуття наукового ступеня канд. мед. наук: 14.01.22 «Стоматолгія» / Х. А. Січкоріз. - Львів: ЛНМУ ім. Данила Галицького, 2017. - 20 с.

5. Создание новых лечебно-профилактических средств в стоматологической практике / А. К. Бошкаева, Р. А. Омарова, К. К. Жалдыбаев [и др.] // Вестник Казахского Национального медицинского университета имени С. Д. Асфендиярова. - 2015. - №3. - С. 259-261.

6. Князькова А. С. Разработка состава и технологии изготовления дентального геля комбинированного действия / А. С. Князькова, О. А. Семкина, Т. В. Фатеева // Фундаментальные исследования. - 2014. - №9(1). - С.110-113.

7. Кривчикова А. С. Сравнительный анализ антимикробных препаратов для лечения хронического генерализованного пародонтита / А. С. Кривчикова, Е. Е. Садкова // Бюллетень медицинских интернет-конференций. - 2015. №10 [електрон. ресурс]. Режим доступу:https://medconfer.com/node/4916.

8. Preus H. R. Microbiologic observations after four treatment strategies among patients with periodontitis maintaining a high standard of oral hygiene: Secondary analysis of a randomized controlled clinical trial / H. R. Preus, G. Dahlen, P. Gjermo, V. Baelum // J Periodontol. - 2015. - №86(7). - P.856865 .

9. Кононова О. В. Обгрунтування антиоксидантної дії медикаментозної композиції для лікування хворих на генералізований пародонтит з психосоматичним стресом / О. В. Кононова // Вісник проблем біології і медицини. -2018. №1(1). - C.355-359.

10. Использование биорастворимого чипа с хлоргексидином для лечения пародонтита у взрослых: клинические и рентгенологические результаты / М. К. Jeffcoat, K. G. Palcanis, T. W. Weatherford [et al.] // Современная стоматология. - 2015. - №4. - Р. 32-36.

11. Bansal S. The effect of endodontic treatment using different intracanal medicaments on periodontal attachment level in concurrent endodontic-periodontal lesions: A randomized 
controlled trial / S. Bansal, S. Tewari, P. Sangwan // J Consery Dent. - 2018. - № 21(4). P. 413-418.

12. Худякова М. Б. Місцева та загальна фармакотерапія запальних захворювань пародонту: навч.метод. посібник / М. Б. Худякова, I. I. Соколова, М. М. Бірюкова. - Харків: ХНМУ, 2018. - 85 с.

13. Федін Р. М. Лікувально-профілактичний гель для місцевої терапії генералізованого пародонтиту / Федін Р. М., Мінько Л. Ю. Патент України № 59748. Дата публ. 25.05.2011.

14. Balouiri M. Methods for in vitro evaluating antimicrobial activity: A review / M. Balouiri, M. Sadiki, S. K. Ibnsoud // Journal of pharmaceutical analysis. - 2016. - №6(2). - P.71-79.

15. Вплив антимікробних препаратів на планктонні та біоплівкові форми бактерій, виділені з хронічних анальних тріщин / I. М. Козловська, Н. Є. Романюк, Л. М. Романюк [та ін.] // Regulatory Mechanisms in Biosystems.. - 2017. №4(8). - C.577-582.

\section{REFERENCES}

1. Ivanova M. A., Mochalov Yu. A., Brekhlichuk P. P., Geley V. M., Martynchuk A. O. The study of sensitivity to antimicrobial agents microorganisms from home purulent inflammation among patients of oral and maxillofacial hospital. Meditsinskie novosti Gruzii. 2019;12 (297):57-63.

2. Singh R., Ramachandra S. S. Resective or regenerative periodontal therapy: Considerations during treatment planning: A case report. N Y State Dent J. 2016;82(4):46-49.

3. Shylivs'kyj I. V., Nemesh O. M., Gonta Z. M. Modern views on the etiology and pathogenesis of inflammatory periodontal diseases, their relationship with the pathology of the urinary system. Bukovyns'kyj medychnyj visnyk. 2016;20(1):224-227.

4. Sichkoriz H. A. Klinichno-laboratorne obg'runtuvannja kompleksnogo likuvannja ta profilaktyky zahvorjuvan' parodonta u hvoryh iz hronichnym gepatytom C [Clinical and laboratory justification of complex treatment and Prevention of periodontal diseases in patients with chronic hepatitis C]: Abstract of a candidate's thesis of medical sciences. L'viv: LNMU im. Danyla Galyc'kogo; 2017:20.

5. Boshkaeva A. K., Omarova R. A., Zhaldybaev K. K., Iskakova M. K., Akhelova A. L. Creation of new therapeutic and preventive means in dental practice. Vestnik Kazakhskogo Natsional'nogo meditsinskogo universiteta imeni S. D. Asfendiyarova. 2015;3: 259-261.

6. Knyaz'kova A. S., Semkina O. A., Fateeva T. V. Development of the composition and manufacturing technology of combined action dental gel. Fundamental'nye issledovaniya. 2014;9(1):110-113.

7. Krivchikova A. S., Sadkova E. E. Comparative analysis of antimicrobial drugs for the treatment of chronic generalized periodontitis. Byulleten' meditsinskikh internetkonferentsiy. 2015;10 [elektron. resurs]. Rezhim dostupu: https://medconfer.com/node/4916.

8. Preus H. R., Dahlen G., Gjermo P., Baelum V. Microbiologic observations after four treatment strategies among patients with periodontitis maintaining a high standard of oral hygiene: Secondary analysis of a randomized controlled clinical trial. J Periodontol. 2015;86(7):856-865.

9. Kononova O. V. Justification of the antioxidant effect of the drug composition for the treatment of patients with generalized periodontitis with psychosomatic stress. Visnyk problem biologii' i medycyny. 2018;1(1):355-359.

10. Jeffcoat M. K., Palcanis K. G., Weatherford T. W., Geurs N. C., Flashner M., Reese M. Use of a bio-soluble chip with chlorhexidine for the treatment of periodontitis in adults: clinical and radiological results. Sovremennaja stomatologyja. 2015;4: 32-36.
11. Bansal S., Tewari S., Sangwan P. The effect of endodontic treatment using different intracanal medicaments on periodontal attachment level in concurrent endodonticperiodontal lesions: A randomized controlled trial. J Conserv Dent. 2018;21(4):413-418.

12. Hudjakova M. B., Sokolova I. I., Birjukova M. M. Misceva ta zagal'na farmakoterapija zapal'nyh zahvorjuvan' parodontu [Local and general pharmacotherapy of inflammatory periodontal diseases] navch.-metod. posibnyk. Harkiv: HNMU; 2018:85.

13. Fedin R. M., Min'ko L. Ju. Likuval'noprofilaktychnyj gel' dlja miscevoi' terapii' generalizovanogo parodontytu. [Therapeutic and preventive gel for local therapy of generalized periodontitis]. Patent Ukrai'ny № 59748. Data publ. 25.05.2011.

14. Balouiri M., Sadiki M., Ibnsoud S. K. Methods for in vitro evaluating antimicrobial activity: A review. Journal of pharmaceutical analysis. 2016;6(2):71-79.

15. Kozlovs'ka I. M., Romanjuk N. Je., Romanjuk L. M., Kuhtyn M. D., Gorjuk Ju. V., Karpyk G. V. Effect of antimicrobials on planktonic and biofilm forms of bacteria isolated from chronic anal fissures. Regulatory Mechanisms in Biosystems. 2017;4(8):577-582.

Надійшла 10.08.2020

UDC 616.314.17-008.1

DOI 10.35220/2078-8916-2020-37-3-24-29

\section{A.A. Dorohina}

Dnepropetrovsk Medical Academy

\section{THE REGULARITIES OF IMMUNOLOGICAL DISORDERS IN PATIENTS WITH THE RAPIDLY PROGRESSING GENERALIZED PARODONTITIS WITH THE DRUG-SENSITIVE AND DRUG-RESISTANT PERIODONTOPATHOGENIC BACTERIA}

\section{ABSTRACT}

Generalized periodontitis is one of the most common d ental diseases and is one of the main causes of tooth loss in young and mature people. Recently, the etiology and pathogenesis of this disease, which is prone to a persistent and aggressive course with unstable results of complex treatment, have become a priority in the study of the problem of rapidly progressive generalized periodontitis. The results of the study are based on a comprehensive clinical and immunological examination of 59 patients with a diagnosis of rapidly progressive generalized periodontitis of I-II and II-III severity, aged 30 to 52 years (the average age was $35.4 \pm 1.4$ years on average), among they were observed 31 (53\%) women and 28 (47\%) men who did not have other general somatic diseases that could affect the immunological status during 